\title{
"Not an Attempt to Coddle Children": Dr. Charles Hegler Gundry and the Mental Hygiene Division of the Vancouver School Board, 1939-1969
}

\author{
Gerald E. Thomson
}

Dr. Charles Hegler Gundry, in his report for the Mental Hygiene Division in 1962/63 to the Vancouver School Board, expressed the view that many of the children he was seeing simply needed to overcome their own emotional problems. As the head psychiatrist for Vancouver's schools since 1939, Gundry had always believed the "aim of mental hygiene is not an attempt to coddle children or over protect them but to try to teach them to want to do what they should do." ${ }^{1}$ Despite some very serious family and emotional problems among these children, Gundry felt the answer was simply a matter of their accepting the social standards of the larger society. In Canadian society during the period following World War Two those social standards demanded a high degree of conformity. Widespread social and economic prosperity had fostered an Anglo middle-class culture in Canada in which family life was idealized around a father as economic provider, mother as domestic nurturer, and a high level of material prosperity in the home. Particular values and behaviours were encouraged through public institutions such as schools as well as media like film, television, and radio. ${ }^{2}$

As a mental hygienist in Vancouver schools for over thirty years, Gundry attempted to control youthful delinquency by affirming the dominance of Anglo middle-class family values. According to Mona Gleason, psychologists in post-war Canada through "their definition of normalcy" actively promoted this new vision of the family. By "normalizing the ideal," Canadian psychology produced a set of unrealistic expectations that only a minority of families outside the emerging Anglo middle-class

\footnotetext{
1 Vancouver City Archives (VCA), Metropolitan Health Committee Minutes, Wednesday, 19 Sept. 1962, Item \#2, Dr. C.H. Gundry: Prevention of Psychiatric Disorders.

2 Neil Sutherland, Growing Up: Childhood in English Canada from the Great War to the Age of Television (Toronto: University of Toronto Press, 1997), x, 37-40, 132-33, 13940.

(C) Historical Studies in Education/Revue d'histoire de l'éducation 14, 2 (2002): 247-78
} 
mainstream could attain. ${ }^{3}$ This social agenda of Canadian psychology had actually begun in 1918 with the formation of the Canadian National Committee on Mental Hygiene (CNCMH) under Doctors Charles K. Clarke and Clarence Hincks. The CNCMH was patterned after the American mental hygiene movement which had begun in 1908. Mental hygiene combined notions of eugenics, psychology, and public health into a unified agenda to halt the spread of mental degeneracy in society. Gleason notes that the early mental hygiene movement in Canada was based upon Anglo middle-class eugenic beliefs of superiority and a distrust of the lower classes of society. ${ }^{4}$ The CNCMH conducted mental hygiene initiatives across Canada through funds derived from the Rockefeller Foundation's Commonwealth Fund. ${ }^{5}$ Psychologists were recruited to deal with problem schoolchildren and their families through child guidance clinics. ${ }^{6}$

Dr. Gundry was engaged in 1939 as Director of the Mental Hygiene Division for the schools of Vancouver. The Metropolitan Health Board of Greater Vancouver used a Rockefeller grant to create a service never before offered in the region's schools: psychiatric therapy for troubled children and their families. Previously, mental hygiene initiatives had largely been directed toward the removal and segregation of feeble-minded schoolchildren. Gundry himself was the product of a psychiatric profession which espoused environmentalism but was still heavily imbued with eugenics. Angus McLaren cautions that "it is important not to exaggerate the gap that separated the eugenicists and environmentalists" because "their goals of efficient social management

3 Mona Gleason, Normalizing the Ideal: Psychology, Schooling and the Family in Postwar Canada (Toronto: University of Toronto Press, 1999), 94-95.

4 Ibid., 22; for mental hygiene see James Trent Jr., Inventing the Feeble Mind: A History of Mental Retardation in the United States (Berkeley: University of California Press, 1994), 179-81; Theresa R. Richardson, The Century of the Child: The Mental Hygiene Movement and Social Policy in the United States and Canada (New York: State University of New York Press, 1989), 45-58, 59-74, 77-86; Neil Sutherland, Children in English-Canadian Society: Framing the Twentieth Century Consensus (Toronto: University of Toronto Press, 1977), 71-78; Sol Cohen, “The Mental Hygiene Movement, the Development of Personality and the School: The Medicalization of American Education,” History of Education Quarterly 23, 2(Summer 1983): 123-49; Ian Robert Dowbiggin, Keeping America Sane: Psychiatry and Eugenics in the United States and Canada, 1880-1940 (Ithaca: Cornell University Press, 1997), 133-90.

5 See for the Rockefeller Mental Hygiene Grants to Canada: Richardson, The Century of the Child, 115-17, 126-27.

6 Gleason, Normalizing the Ideal, 27. 


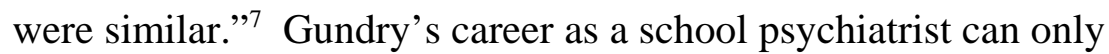
be fully understood within this theme of efficient social management as endorsed by Canadian eugenicists, mental hygienists, and psychiatrists from the early- to mid-twentieth century. Gundry expressed many of the social prejudices long held sacred by the eugenics movement, such as the inferiority of the lower classes and their predisposition to social misconduct. He represented a historical transition in the practice of psychiatry itself from a rigid hereditarianism in which people were simply assumed to be born inferior, to a belief that poor environments created troubled people. His efficient social management of problem children tended to be concentrated within the multi-cultural, working-class regions of east Vancouver and targeted that school population. This article will briefly discuss the Canadian context of mental hygiene and then analyze Dr. Gundry's career as a mental hygienist in Vancouver's schools.

\section{Mental Hygiene: The Canadian Context.}

A growing body of research suggests Canada's experience of mental hygiene followed a different course from that of the United States. Theresa Richardson's history of mental hygiene in North America, The Century of the Child (1989), describes the Canadian movement as "similar to the United States...in that it popularized a medical perspective in eliminating social problems prior to any substantial advances in scientific research."8 Canada's mental hygiene movement employed its collective medical and moral authority to curtail the civil rights of individuals in the name of building a better society. Provinces like Alberta enacted harsh social measures such as forced sterilization of the mentally unfit. Despite such facts Canadian mental hygienists portrayed themselves as public health reformers. ${ }^{9}$ Canada's mental hygiene movement remained small and lacked "professional strength" compared to its counterpart in the United States. ${ }^{10}$ However, the Canadian mental hygiene movement consistently advocated the sterilization of the socially unfit as late as the 1940s; these eugenic

7 Angus McLaren, Our Own Master Race: Eugenics in Canada, 1885-1945 (Toronto: McClelland and Stewart Press, 1990), 112.

8 Richardson, The Century of the Child, 73.

9 Ibid., 73.

10 Ibid., 74. 
policies of the CNCMH must be linked to the successful passage of sterilization laws in Western Canada. ${ }^{11}$ Considering the impact of recent legal settlements in Alberta awarded to sterilized individuals, such a linkage is critical. ${ }^{12}$

The mental hygiene movement in North America was a powerful lobby group that crafted social policies towards the mentally handicapped by promoting sterilization laws, shaping educational policy by emphasizing hereditarianism, and ultimately convincing politicians about the scientific validity of non-Anglos as mentally inferior. ${ }^{13}$ Canada had a small committed group of mental hygiene professionals in the CNCMH who were actively promoting eugenic ideas long after they had fallen out of favour in the United States. Richardson cites child psychiatrist William Emet Blatz as the leading authority on Canadian children and education during the interwar period. However, Dr. Peter Sandiford, a psychologist at the University of Toronto and $\mathrm{CNCMH}$ member, was decidedly more prominent and he consistently advocated the forced sterilization of the feeble-minded. His professional influence lasted from the 1920s until well after World War Two. ${ }^{14}$

The more complex story of Canadian mental hygiene first emerged in the work of Neil Sutherland, who devoted a brief chapter in Children in English-Canadian Society (1976) to the links between the child health movement and hereditarian concerns about the racial decline of Canadian society. After 1900 a Canadian mental hygiene and eugenics movement was "patched

11 McLaren, Our Own Master Race, 109, 158-59; Alberta, 100; B.C., 103-5.

12 Richardson, The Century of the Child, 65-66, 74; for the LeiLani Muir case see "The Case of LeiLani Muir,” National Film Board of Canada, 1995.

13 For a general guide to American Eugenics see Daniel Kevles, In The Name of Eugenics: Genetics and the Uses of Human Heredity (Berkeley: University of California Press, 1985); Mark H. Haller, Eugenics: Hereditarian Attitudes in American Thought (New Brunswick: Rutgers University Press, 1963); Diane Paul, Controlling Human Heredity: 1865 to the Present (Atlantic Highlands: Humanities Press, 1995); for American education see Steven Selden, Inheriting Shame: The Story of Eugenics and Racism in America (New York: Teachers College Press, 1999); for eugenics and immigration/race restrictions see relevant passages in Kevles, Haller, and Paul. For an overview see John Higham, Strangers in the Land: Patterns of American Nativism, 1860-1925 (New York: Athenaeum Press, 1974).

14 Richardson, The Century of the Child, 117-23; for Peter Sandiford see McLaren, Our Own Master Race, 61-63, 110; George S. Tomkins, A Common Countenance: Stability and Change in the Canadian Curriculum (Scarborough: Prentice-Hall Press, 1986), 177, 180-81, 183; Robert S. Patterson, "Society and Education During the War Years and Their Interlude: 1914-1945,” in Canadian Education: A History, ed. J. Donald Wilson, Robert M. Stamp, and Louis Philippe Audet (Scarborough: Prentice-Hall Press, 1974), 372. 
together," with one of its main efforts being directed towards the segregation of "feeble-minded youngsters" and the curbing of the procreative power of feeble-minded parents. Sutherland characterizes the CNCMH's “obsession with sorting out and locking up the feeble-minded" as socially provocative by the 1920s; he also notes the CNCMH's attack on non-Anglo immigrants because it regarded them as inferior human stock and their offspring as the product of "degraded parentage."15

In George S. Tomkins' historical survey of Canadian curriculum development, A Common Countenance (1986), the social theories of mental hygienists are described as "alarmist and even hysterical in tone.” Tomkins cites comments made by Peter Sandiford in 1914 on behalf of Canadian mental hygienists concerning the control of the feeble-minded: "We want no lethal chambers but we do want homes where those unfortunates...will be prevented from adding defective offspring to the already heavy burdens of normal society." "It was the CNCMH which advised local school boards "to keep its normal children free from sources of contamination" by feeble-minded children by creating segregated special classes for sub-normal students. Tomkins was quite clear on the continued influence of eugenics during the 1920s despite the growing academic ascendency of environmental theories. ${ }^{17}$

Tomkins creates a picture of a highly effective Canadian mental hygiene movement that introduced a number of social and educational measures into Canadian society. Special classes for subnormal children, sterilization, institutional confinement, educational testing or psychometrics to classify school pupils by intelligence, child guidance services such as school psychiatrists, the use of mental health counsellors, and the creation of a school guidance curriculum to encourage good mental health were all first advanced by the CNCMH. Tomkins believes mental hygiene acted to "medicalize the professional language of educators" and change the way they regarded children. ${ }^{18}$

The first comprehensive history of Canada's mental hygiene movement was Our Own Master Race (1990), by Angus McLaren. His work documents the efforts of mental hygienists to halt the immigration to Canada of defective aliens, the campaign to

15 Sutherland, Children in English-Canadian Society, 71-77.

16 Tomkins, “Medicalizing the Curriculum 1920-1945,” A Common Countenance, 177.

17 Ibid., 178-79.

18 Ibid., 186. 
establish special classes for subnormal children, the successful passage of forced sterilization laws in British Columbia and Alberta, along with the widespread influence of eugenic ideas through what he describes as biological politics. Even leading figures on Canada's political left were captivated by eugenics, like Tommy Douglas, who submitted a Master's thesis in 1933 on "The Problems of the Subnormal Family.” Douglas was fascinated by eugenic's promise of scientific perfectibility for human society. ${ }^{19}$ McLaren's work makes a strong argument that eugenics was sustained in Canada far longer than in the United States.

As late as 1946 the CNCMH was still publishing prosterilization tracts urging stronger eugenic laws in Canada. In a 1946 article entitled "Sterilize the Unfit," Clarence Hincks declared the war had decimated the good stock of Canada and the remaining "fit" breeding stock had to be protected. To Hincks, the unfit were the ethnic minorities or new Canadians who were increasing their numbers through post-war immigration, while the good stock were Canadians of Anglo descent. From 1928 to 1971 Alberta sterilized 2,822 people, many of whom came from minority backgrounds. ${ }^{20}$

English Canada was schooled in notions of race improvement in order to attain a truly Anglo, Christian nation. Eugenic ideas were simplistic but seductive as high school and college biology text books used in Canada gave eugenics "respectful attention." 1 As late as 1978 a Scarborough, Ontario, mother raised a national outcry when she took her troubled daughter for medical help and it was suggested she be sterilized. ${ }^{22}$ McLaren's work stresses the practical impact of mental hygiene measures on the lives of many Canadians in the last century. ${ }^{23}$

Ian Robert Dowbiggin's history of psychiatry in North America from 1880 to 1940, Keeping America Sane (1997), provides further insight into Canadian mental hygiene. He shows that CNCMH support for sterilizing the mentally unfit lasted well into the 1940s despite the influence of genetics and environmentalism. In 1934 Clifford Beers, a founder of the American mental hygiene movement, wrote to the CNCMH about their continued support for sterilization because it was "damaging

\footnotetext{
19 McLaren, Our Own Master Race, 8-9.

20 Ibid., 158-59.

21 Ibid., 167.

22 Ibid., 169-70.

23 Ibid., 166-68.
} 
the entire mental hygiene movement."24 Dowbiggin believes eugenics remained strong in Canada long after its influence had waned in the United States because of the dominance of eugenicminded doctors. Only hereditarian scientists were placed in positions of power within Canadian psychiatry by the CNCMH. Such was the case of Dr. Clarence B. Farrar, enticed to Canada in 1923 to become head of the University of Toronto's Psychiatric Hospital in 1925. Farrar praised sterilization legislation and denounced opposition to such measures as hysterical. ${ }^{25}$ Dowbiggin concludes that the CNCMH's eugenic influence was long-lasting because it strongly influenced the professional outlooks of psychiatrists. ${ }^{26}$

Canada's mental hygiene movement maintained a strong adherence to eugenic notions of hereditarianism far longer than its American counterpart. A stark example is Arthur Beall's The Living Temple (1933), which was used as a health textbook in Canadian schools until after the Second World War. Beall told girls to guard their purity and cautioned boys about not "bleeding away the life fluid" in order to keep the race strong. ${ }^{27}$ He stressed notions of Christian superiority and encouraged greater Anglo middle-class reproduction. His textbook was a crude example of how eugenic notions were popularized in Canada.

\section{Dr. C. H. Gundry: Vancouver's Mental Hygienist.}

\section{A. The Early Medical Career of Dr. C.H. Gundry and the Creation of Vancouver Schools' Mental Hygiene Division}

Dr. C.H. Gundry was born in Brantford, Ontario, on March 2, 1906, and spent his youth in Galt. He attended the University of Toronto in the mid-1920s and graduated with a medical degree in

\footnotetext{
24 Dowbiggin, Keeping America Sane, 182n127.

25 Ibid., 183-85.

26 Ibid., 189.

27 Arthur W. Beall, The Living Temple: A Manual for Eugenics for Parents and Teachers (Whitby: A.B. Penhal Press, 1933), Lesson 9 and 10, "Life Fluid and Glands," 60-74. For comments on Beall see Tomkins, A Common Countenance, 177, and McLaren, Our Own Master Race, 70-71.
} 
$1930 .^{28}$ While in medical school, Gundry received his training in psychiatry during the tenure of Dr. Clarence B. Farrar, who had been educated at John Hopkins medical school and from 1931 to 1965 was the editor of the American Journal of Psychiatry. Farrar's influence on Canadian psychiatry was immense and he remained convinced that heredity was the primary cause of mental illness. Shortly after arriving at Toronto’s Psychiatric Hospital, Farrar told the Children's Aid Society that "the complete sterilization of mental deficients to prevent procreation of mental defectives" was a social necessity. ${ }^{29}$ In 1931 Farrar published an article on "Sterilization and Mental Hygiene" in the Canadian Public Health Journal which recommended the routine sterilization of "impoverished parents" of "inferior stock." 30 Farrar's lectures were apparently so compelling that medical students skipped other classes in order to hear him. ${ }^{31}$ His lectures were filled with Anglo middle-class prejudices against the ethnically diverse lower segments of society.

In late 1930 Gundry left Canada to complete his post-graduate work in child psychiatry at the Cleveland Child Guidance Clinic. Richardson identifies the Cleveland, Ohio, program as one of eight Commonwealth Fund demonstration sites for the "Prevention of Delinquency." Their mission was to demonstrate, "on a community level, the applicability of psychiatry to problems of childhood, specifically delinquency as a symptom of early mental disease." In fact the Cleveland program became noted for its use of schools and social agencies in trying to avert chronic delinquency. ${ }^{32}$ The practitioners of mental hygiene believed the untreated delinquent youths of today become the mentally ill of

\footnotetext{
28 "Gundry, Charles Hegler," Biographical Dictionary of Fellows and Members of the American Psychiatric Association (New York, 1941), 163; "Dr. Charles Hegler Gundry," Canadian Medical Association Journal 101-441 (4 Oct. 1969): 121; "Mental Hygiene Pioneer Dies,” Vancouver Sun, 29 July 1969, 10; “Dr. Gundry Funeral Set Today,” Daily Province, 30 July 1969, 10.

29 Edward Shorter, “C.B. Farrar: A Life,” in TPH: History and Memories of the Toronto Psychiatric Hospital, 1925-1966, ed. Edward Shorter (Toronto: Wall and Emerson Press, 1996), 83-84. For the eugenic leanings of C.B. Farrar see Dowbiggin, Keeping America Sane, 184-86, and McLaren, Our Own Master Race, 128.

30 McLaren, Our Own Master Race, 205, 119n67.

31 W. Clifford M. Scott, "Experiences of a Student Intern at TPH," in TPH, ed. Shorter, 184.

32 Richardson, The Century of the Child, 91, 102.
} 
tomorrow. ${ }^{33}$ The following excerpt is from a medical textbook of the same time period:

The patients who will be received by the institution ten, fifteen, twenty years from today are in our public schools and many of them are even now showing behavior abnormalities that stamp them as potential deviates. It seems clear that the state...has a grave responsibility in this field of prevention and must prepare to assume that duty...

The text went on to proclaim that "it is the golden age for mental hygiene." 34

It was in this golden age that Dr. Gundry completed his studies in child psychiatry. Eugenic prejudices against the lower classes of society, non-Anglo immigrants and the feeble-minded were not simply cast aside by mental hygienists in the late 1930s. While adopting new attitudes about the prevention of mental illness through therapeutic intervention, Gundry was taught to regard the transmission of mental defects as being a hereditarian mechanism.

Upon returning to Canada, Gundry joined the medical staff of the Brockville Psychiatric Hospital from 1932 to 1934. In 1935 he moved to the Mental Health Clinic of the New Toronto Hospital, where he stayed until 1936. In 1937 he returned to Brockville and in 1938 he applied for the position of school psychiatrist in Vancouver. At some point in the mid-1930s, Gundry undertook additional post-graduate training in Cleveland. ${ }^{35}$ In 1939 he commenced his duties as Director of the Mental Hygiene Division of the Metropolitan Health Board. The agency represented a new regional approach to public health services in the schools as well as the enforcement of public health standards. Planning for the Health Board had begun in 1932 by Lower Mainland civic councils and school boards. It was anticipated that in addition to provincial funds "the municipalities would receive an annual grant for a period of years from the Rockefeller Foundation" to help finance the scheme. ${ }^{36}$ In October of 1936 the Metropolitan Health Board

33 William A. Bryan, Administrative Psychiatry (New York: W.W. Norton Press, 1936), 287.

34 Ibid.

35 “Dr. Charles Hegler Gundry,” Canadian Medical Association Journal, 121.

36 "Metropolitan Health Board Proposal Should Be Carefully Investigated," Vancouver Star, 7 Jan. 1932. 
began operations with an overall budget of $\$ 36,080$, of which $\$ 13,309$ was provided by the Rockefeller Foundation, $\$ 13,309$ by the province, and the remaining $\$ 9,462$ by municipal governments. ${ }^{37}$

The 1937 organizational plan of the Metropolitan Health Board specifically created two separate departments for the school system. The School Medical Service would look after the physical needs of the pupils while a new Child Welfare and Mental Hygiene Department would attend to the emotional, social, and psychological needs of school children. The director of the Mental Hygiene Department was to be "a physician trained in Paediatrics \& Mental Hygiene" who could organize "the preparation of a program of Child Welfare and Mental Hygiene for the whole Metropolitan Area."38 However, the position of mental hygienist remained vacant throughout 1937 and into 1938. In the fall of 1938 two finalists had been selected: Dr. A.G. McGugan of Edmonton and Dr. C.H. Gundry of the Ontario Hospital Service. Dr. Gundry was willing "to take a special combination course at the University of Toronto to further his qualifications." ${ }^{39}$ On December 21, 1938, the committee agreed "the position be offered to Dr. C.H. Gundry, as he appeared to be the best qualified candidate." 40

\section{B. A New Approach to Problem Schoolchildren in Pre-World War Two Vancouver}

When Dr. Gundry arrived in Vancouver as its first mental hygienist he brought a new method of dealing with schoolchildren experiencing learning problems. Previous attempts at mental hygiene in the schools had centred around the segregation of feeble-minded and delinquent children. ${ }^{41}$ Gundry introduced the concept of psychiatric intervention in order to avert a child's decline into delinquency. He had been trained in the mental hygiene perspective that some children were simply handicapped

\footnotetext{
37 “Greater City in Health Unit: Metropolitan Board Becomes Reality on Sunday,” Daily Province, 31 Oct. 1936, 14.

38 VCA, Dr. G.F. Amyot, Report of the Proposed Metropolitan Health Department for the Greater Vancouver Area, 1936, 12.

39 VCA, Metropolitan Health Committee Minutes, Wednesday, 16 Nov. 1938, 64-65.

40 Ibid., Wednesday, 21 Dec. 1938, 67.

41 For a history of early mental hygiene in Vancouver schools, see Gerald E. Thomson, "Remove From Our Midst These Unfortunates" (Ph.D. diss., University of British Columbia, 1999), and McLaren, Our Own Master Race, 92, 94-95.
} 
by their birth and had to be actively resocialized. Social unfitness required psychiatric treatment and possible removal of the child from the corrupting environment in order to save him or her from a deviant adult life. Gleason believes it was "the growing acceptance of environmental factors in determining mental hygiene" that caused a "decline in the acceptance of eugenic reasoning.” In Canadian psychology the works of William Blatz and Samuel Laycock were pivotal. ${ }^{42}$ However, there are no clear demarcation lines in intellectual trends; many psychiatrists of Gundry's era may have espoused environmental theories and preventive measures but still held strong class prejudices that were eugenic in their overtones. They retained the harsh judgemental nature of eugenicists about the social inadequacy of particular segments of society.

Shortly before Gundry came to Vancouver in 1939 he attended a medical conference in Cornwall, Ontario, at which he outlined his focus as a mental hygienist. Although he incorporated ideas from Blatz and Laycock about a loveless childhood, his condemnation of the adults who lie, swindle, and malinger was more akin to the eugenicist's scorn of the feeble-minded. ${ }^{43}$ Gundry wrote:

Many of the adults who are unreliable and unstable, whose employment records are unsatisfactory, who are continually disappointing those who try to help them, and who are often malingerers, liars and swindlers, in short, the psychopathic personalities, have a history of a loveless childhood. They have never learned to respect the authority of a father they loved, and, consequently, always tend to resent authority. ${ }^{44}$

In 1940 Gundry wrote that a child's bad behaviour "should be regarded as a symptom" as the explanation lay "in his environmental and his physical and mental make-up.” All mental problems in adult life could be traced back to "unwholesome

42 Gleason, Normalizing the Ideal, 42-43.

43 Ibid., 107-8 (Blatz), 84 (Laycock); Blatz believed normal children were the products of good parental upbringing and "were secure in themselves"; Laycock saw marital breakdown as the cause of children failing to develop social attachments. For both, the "crippled personalities" of children could be found in their family circumstances. Middleclass families were idealized by Blatz and Laycock as creating healthy adults.

44 C.H. Gundry, "Modern Trends in Child Psychiatry," The Canadian Medical Association Journal 39, 1 (July 1938): 48. Cited as an address given to the Cornwall Medical Society, 12 Nov. 1937. 
compensations...in childhood.” ${ }^{45}$ A year before, Gundry had been interviewed by a daily newspaper about his work with schoolchildren. He claimed a cure for troubled children was elusive but therapy was "able to forestall a great deal of neurotic disability." ${ }^{46}$ In November, 1939, Gundry offered his advice to the professional group with whom he would work most closely. In "Our Bad Boys," Gundry told teachers that "we no longer believe that children are born bad." Their problems arose from "emotional stresses" brought on by "insecurity." The teacher's role was to collect "data" in order to give the doctor a proper "understanding of a child's behaviour." 77 Cases of "poor personality" would be referred to the mental hygienist, declared Superintendent of Schools, H.N. MacCorkindale. It was stressed that parents and the child were to "look upon the conference as a medical examination inquiring into the health of the pupil rather than any mental irregularity." 48 During Gundry's first year of work a pattern emerged of citing the impoverished circumstances of families as the prime source of a child's distress.

In 1939/1940 Gundry dealt with 127 cases, of which 47 required long-term therapy. There is no indication where the "cases" came from in the city, what they were being treated for, or the sex ratios. Detailed data would not be provided in Gundry's reports until after the war. He summarized his clinical method for the newspaper article: "We just chat about things, and bye and bye we get important clues to the temperament." Children often developed "bad compensation habits" because of family conflicts. ${ }^{49}$ In 1941 Gundry left for war service as an army psychiatrist but not before devising a course on mental hygiene for teachers at the Provincial Normal School. ${ }^{50}$ Gundry's work was seen as so valuable that a replacement, Dr. Mary Luff, was secured for him from Great Britain in June, 1941. She would continue his work

45 C.H. Gundry, “Mental Hygiene and School Health Work,” Canadian Public Health Journal 31, 10 (Oct. 1940): 485.

46 Margaret Ecker, “Children's Troubles Threshed Out in Vancouver Clinic,” Saturday Province Magazine, 25 Nov. 1939, 7.

47 Dr. C.H. Gundry, “Our Bad Boys,” The B.C. Teacher 19, 3 (Nov. 1939): 139-40.

48 VCA, H.N. MacCorkindale, "Health Services,” Vancouver Board of School Trustees (hereafter Vancouver BST) Annual Report for 1939/1940, 44-46.

49 VCA, "Report of the Chairman of the Board 1940-Health Services," Vancouver BST Annual Report for 1939/1940, 83-84; Ecker, "Children's Troubles Threshed Out."

50 "Gundry, Charles Hegler," Biographical Dictionary of Fellow and Members of the American Psychiatric Association, 163. 


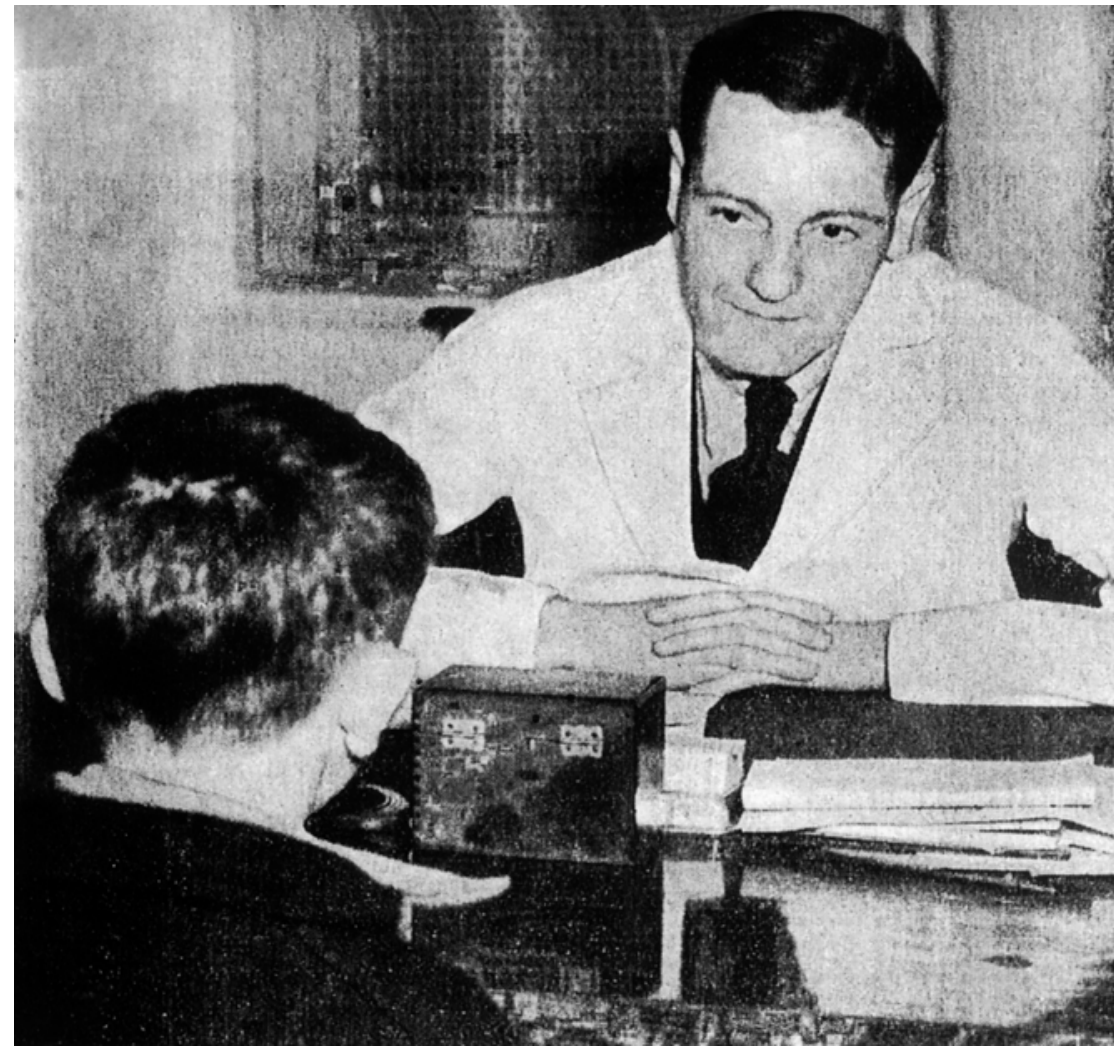

with Normal School teachers. ${ }^{51}$ In the army Gundry rose to the rank of major and advocated the placement of people within the armed forces using mental examinations. ${ }^{52}$ In 1946 he returned to full-time work in Vancouver schools, where his judgemental attitude concerning the children of working-class families from ethnically diverse areas of the city would begin to emerge.

51 VCA, H.N. MacCorkindale, “Health” and “Medical Health Services,” Vancouver BST Annual Report for 1941/1942, 17, 42.

52 VCA, Metropolitan Health Committee Minutes, Wednesday, 19 Nov. 1947, Item 5, “Address by Dr. Gundry,” 309. 
Dr. C.H. Gundry examining a Vancouver elementary school pupil in 1939. The caption to the photograph reads: "We just chat about things."

Source: Margaret Ecker, "Children's Troubles Threshed Out in Vancouver Clinic,” Saturday Province Magazine, November 25, 1939, p. 7.

\section{Mental Hygiene in a City Divided: Post-Second World War Mental Health Initiatives in Vancouver's Schools}

Gundry first planned to refine the conference method or "chats" he had with problem pupils. He stressed that parents had to understand that such behaviours as temper tantrums "may be the 
seed of future disability and lack of restraint” in their children. Gundry was convinced that early psychiatric intervention was necessary as many of the "psychiatric casualties" that he saw in "adults during military service" clearly indicated the "need for extensive and consistent attempts to improve the mental health of our children."53

Gundry publicly spoke out about an eighteen-year-old youth who killed a North Vancouver man in 1945. He used the event to illustrate the importance of psychiatric interventions with troubled children. The Russell murder trial of 1946 proved to Gundry the need for early mental hygiene treatment "as Russell was alleged to have developed" a "condition" during "his childhood years." Gundry concluded it was a simple case of "an ounce of prevention is worth a pound of cure" when dealing with juvenile mental problems. ${ }^{54}$ He began to campaign for the extension of mental hygiene by appealing to alarmist sentiments much like the eugenicists. Throughout the 1950s a pattern emerged in Gundry's work of trying to impose the norms of middle-class family life upon the children of the city's working-class districts through mental hygiene initiatives. Although children from across Vancouver did receive psychiatric treatment, a staggering number of Gundry's young patients were drawn from the working-class areas of east and south Vancouver with their growing populations of new immigrants.

In his 1947 report Gundry speculated that "normal children" existed in "large numbers" as opposed to the minority of "others whose progress and development" was abnormal. The "job at hand" for schools and health departments was to provide mental hygiene training for their frontline staff to deal with the abnormal. Without early detection and treatment we would "face a chaotic future.” The first detailed statistics appear in Gundry’s 1947 report and over 164 new cases along with 50 follow-ups were treated during that year. The majority were for poor academic progress (60) and stealing (40), poor adjustment (41), truancy (24), sexual problems (7), as well as a myriad of other negative behaviours. "Reading disability" was the problem cited in eight pupil referrals. The main diagnosis given was not a specific type of psychosis but rather a "dull normal and borderline intelligence" rating which accounted for 37 cases. Two children were placed in the "mental

53 VCA, Report of Dr. C.H. Gundry, Mental Hygiene Division, for 1946, 1-2. 54 “Abnormality and Criminality,” Vancouver Sun, 10 Feb. 1947, 4. 
institution at New Westminster" and fifteen parents were referred to "psychiatric treatment." No distinction by sex was provided in the statistics until 1950 and ethnic background was never mentioned. ${ }^{55}$ The parents of an abnormal child could be forced by Gundry into treatment for their faulty child-rearing practices; this situation did not change until the late 1950s. This illustrates Gundry's and indeed Canadian psychiatry's absolute authority over children and their parents.

In 1948 Gundry's case data began to specify the Vancouver schools from which the individual children came. Drawing from the literature on the city's geographical and social division, it is possible to discern from which social strata his cases originated. Vancouver has been historically divided between the mostly affluent west side and the working-class east side along the north/south axis of Cambie and Main streets. Robert A.J. McDonald in his history of Vancouver before World War One states that the east side "tended to be more working class and the west more middle and upper class." South Vancouver from Marpole to the east was populated by the "industrial classes," while to the west it was "more uniformly white collar."56 The school map from 1936 reproduced here illustrates this east/west divide.

Of Gundry's 209 new cases and 41 follow-ups for 1948, 184 came directly from the Vancouver school system. Poor school progress was the leading cause of pupil referral (65) and 26 were diagnosed as simply being of dull/borderline intelligence. About 39 were sent for academic adjustment or remedial education, 38 for vocational training, 4 children were admitted to a mental institution, and 5 parents were referred for psychiatric treatment. A closer examination of the school data reveals a marked bias towards schools in the east end and south Vancouver patronized by the children of working-class and immigrant parents. Dawson, in the

55 VCA, Report of Dr. C.H. Gundry, Mental Hygiene Division, for 1947, 1-3; VCA, H.N. MacCorkindale, “Mental Hygiene,” Vancouver BST Annual Report for 1947/1948, 46.

56 Robert A.J. McDonald, Making Vancouver: Class, Status, and Social Boundaries, 1863-1913 (Vancouver: UBC Press, 1996), 193. 
Not an Attempt to Coddle Children 
city's core, referred 12 pupils; Franklin and McBride in the east end each referred 8 pupils; while Seymour, in one of the poorest neighbourhoods of the east end, also referred 8 students. Of the west-side schools, only Kerrisdale referred 8 pupils, although this particular area of the west side was largely white-collar. ${ }^{57}$

The east side of Vancouver would become a geographical focus for mental health professionals who worked in Vancouver's schools in the late 1940s and 1950s. The population of the area was changing rapidly after World War Two as Italian, German, and Greek immigrants settled in significant numbers to live alongside older populations of Chinese as well as Japanese-Canadians. ${ }^{58}$ Special counselling projects and psychiatric social work initiatives would be located in the schools of east and south Vancouver. Mental hygiene became a treatment for poor academic performance and behaviour problems among many of Vancouver's workingclass schoolchildren.

In 1949/1950 Gundry expanded his staff in the Mental Hygiene Division. Dr. W.R.S. Wilson took a training program in psychiatry at Gundry's old alma mater, the University of Toronto. Miss Hall, a staff psychologist, went to Toronto's Hospital for Sick Children with the help of a CNCMH grant to obtain experience in paediatric psychiatry. In her absence Ruby Kerr transferred from her position as school psychologist to the Mental Hygiene Division. Kerr was one of Vancouver's first special-education teachers and an advocate of eugenic sterilization for the feeble-minded. ${ }^{59}$ Gundry hoped both Hall and Kerr would remain so that "more individual treatment" could be carried out. A psychiatric social worker for schoolchildren, Harry Itzkow, was hired with financial help from the Vancouver Children's Aid Society. In Gundry's report to the School Board he revealed that the bulk of the salaries allotted for these new positions was "being paid from funds obtained under the Federal Health Grants.” 60 There was a larger federal presence after World War Two in the field of mental health. It was part of the evolving social welfare state in which the government took over the

57 VCA, Report of Dr. C.H. Gundry, Mental Hygiene Division, for 1948, 1-7.

58 Walter G. Hardwick, Vancouver (Don Mills: Collier-Macmillan Press, 1974), 115-16; Norbert Macdonald, "Population Growth and Change in Seattle and Vancouver, 18801960," in Historical Essays on British Columbia, ed. J. Friesen and H.K. Ralston (Toronto: McClelland and Stewart Press, 1976), 218-20.

59 For Ruby Kerr see Gerald Thomson, "Remove From Our Midst These Unfortunates,” 154, 157-61, 175, 225, 228-36, 243-44.

60 VCA, Dr. C.H. Gundry, "Mental Hygiene,” Vancouver BST Annual Report for 1948/1949, 118-19. 
charity and philanthropic work of groups like the Rockefeller Foundation and the CNCMH. This is why mental hygiene initiatives became widespread, unlike their eugenic predecessors.

However, one should not discount the influence of the CNCMH on Vancouver schools in the 1950s. Missing from Gundry's official report to the School Board for 1949/1950 is information found in his yearly department reports. Russell Mackenzie, a Vancouver teacher, returned from a year's training in mental hygiene in Toronto under a plan developed by the CNCMH. The role that Mackenzie would fill in the school system was not clear by the end of 1949. In 1950 Gundry wrote that Mackenzie was "continuing to work very successfully in Templeton Junior High School, and in the seven elementary schools that feed into Templeton Junior High.” What exactly Mackenzie was doing in the heart of Vancouver's east side was outlined in his own report of April 26, 1950. He conducted 415 student and 84 parent interviews, dealt with 247 mental health problems in the classroom brought to light by teachers, and held 37 clinical conferences with school personnel about delinquent youth. He gave 59 talks on "human relations" in high school classrooms, showed "mental health films" on 22 occasions, and did 48 "sociometric studies of class group relations." His work was meant to augment the counselling services of Templeton and its area elementary schools. Mackenzie did a great deal of work with the juvenile court system and probation officers. He also helped to organize diagnostic clinics for Gundry at Templeton and its feeder elementary schools. Although Mackenzie was officially called a "Mental Health Coordinator," his April report was less than specific about his overall purpose. However, a June 1950 letter of support for his Templeton program by Superintendent H.N. MacCorkindale clearly outlined that Mackenzie, along with Gundry, was dealing with "several children who show signs of behaviour symptoms." The work he had done with these "behaviour cases" received high praise from school officials. MacCorkindale believed "we are on the right track for relating the teacher problem of the classroom with the Mental Health problem of the physician and nurse." ${ }^{61}$ It should be

61 VCA, Report of Dr. C.H. Gundry, Mental Hygiene Division, for 1949, 1-6; VCA, Report of Dr. C.H. Gundry, Mental Hygiene Division, for 1950, 1-6; VCA, Russell K. Mackenzie, Report of My Activities as Mental Health Co-ordinator in the Vancouver Schools, for the First Seven Months, April 26, 1950, 1-2; VCA, Letter of 30 June 1950 from Superintendent H.N. MacCorkindale to Dr. F.T. Fairey, Deputy Minister of Education: Re: Training of Teachers in Mental Health Through the Mental Hygiene 
stressed that Templeton Junior High and the feeder schools of Franklin, Begbie, Hastings, Nelson, Macdonald, Seymour, and Woodland are in the geographic centre of working-class east Vancouver.

Mackenzie's work with the schoolchildren of east-side Vancouver was focused on behaviour problems which often resulted in juvenile court involvement. He was following a pattern of social control through education similar to that exhibited by eugenicists in their campaign against lower-class feeblemindedness and its resulting criminality. ${ }^{62}$ Gundry's own 1949/1950 school case data reveal that Templeton Junior High provided ll cases, Franklin 8, Begbie 17, Hastings 1, Nelson 9, Macdonald 5, Seymour 8, and Woodland 5, for a total of 64 cases. Only Strathcona in the east end's most impoverished neighbourhood of the same name had more individual cases at 20 than Templeton or any of its feeder elementary schools. Moberly, in working-class south Vancouver, had 16 cases in 1949/1950. West-side school totals were marginal: General Gordon had 7 cases, Bayview 7, Kitchener 7, Point Grey High School 7, Prince of Wales High 4, and only the blue-collar anomaly of Kerrisdale provided an unusually high 17 cases. The norm on the west side was a small mental hygiene caseload. The first sex ratio data displayed a remarkable split in Gundry's caseload with 129 boys to 64 girls. ${ }^{63}$ Mackenzie and Gundry's efforts in the east-side schools were also being supported by the newly hired psychiatric social worker, Harry Itzkow.

In 1951 Dr. Gundry left for three months to work in Thailand under a World Health Organization grant to further mental health services in developing countries. ${ }^{64}$ Dr. Syd Kaplan took Gundry's place and the staff psychologists began to use psychotherapy to deal with reading failure in children. Misses Hall and Kerr believed that a "blocking or mental set against reading" had been

Fellowship, 1-2. For a recent study of the use of documentary films made by the National Film Board of Canada to promote mental hygiene in school classrooms, see Brian Low, "Graduation Day: Schooling for Mental Health in the Cinematic Society of the National Film Board of Canada, 1940-1980" (Ph.D. diss., University of British Columbia, 1998). 62 For the "Menace of the Feeble-minded" see Trent, Inventing the Feeble Mind, 131-83. 63 VCA, Report of Dr. C.H. Gundry, Mental Hygiene Division, for 1949, 6; VCA, Report of Dr. C.H. Gundry, Mental Hygiene Division, for 1950, 7. School case totals combined.

64 “City Doctor Starts Asian Job For UN,” Daily Province, 6 Sept. 1951, 5; VCA, Report of Dr. C.H. Gundry, Mental Hygiene Division, for 1951, 1; VCA, Metropolitan Health Committee Minutes, Wednesday, 20 Feb. 1952, 27-28: Dr. C.H. Gundry: Experiences in Thailand. 
formed by the child and teachers should make an "early referral to the mental hygiene clinic.” In fact out of the 205 new cases and 57 repeat examinations in 1951, over 131 were initiated due to "poor school progress." There were 8 cases of "arithmetic disability" dealt with and 16 cases of "reading disability." Although no indication is given it is likely that a large number of the students having academic problems were from immigrant households. There were some 66 cases of "negativism," 35 parents were referred for psychiatric treatment, and 7 pupils were placed in a mental institution. The majority of cases (180) were boys and the minority (80) girls. The school referring the most children to Gundry was Begbie in the east end, which provided 16 cases. ${ }^{65}$ With the rise in the amount of negative behaviours, Gundry decided to focus upon an "assessment of social pathology." 66

In 1952 and 1953 the name of Harry Itzkow, the psychiatric social worker, became more prominent in Gundry's reports. Itzkow had trained in the School of Social Work at the University of British Columbia but in 1952 decided to take graduate courses in social work at Columbia University in New York. ${ }^{67}$ In 1953 the Vancouver School Board, through the Mental Hygiene Division, assigned a psychiatric social worker to Lord Roberts, Dawson, and Seymour elementary schools. The report stated that the "social worker assisted the teachers with pupils who showed evidence of an emotional problem." 68 In Gundry’s report for 1953 the majority of the cases are boys (169) with only a small number of girls (81). It was noted that "Mr. Itzkow is confining his efforts to Unit 1, and devoting his chief efforts to three schools, spending one morning a week in each."69 Unit 1 covered the immigrant/working-class east-end neighbourhoods of Strathcona, Grandview/Woodland, and the Hastings area, as well as the downtown/west-end region. In 1954 Itzkow published his own report, noting 104 case conferences and discussions of 209 pupils from within Unit 1. He worked closely with 16 families from Lord Roberts school, helping them with their troublesome boys. This group work resulted in "definite indications of attitude and behaviour change.” At Dawson school

65 VCA, Report of Dr. C.H. Gundry, Mental Hygiene Division, for 1951, 7.

66 VCA, “Metropolitan Health Services,” Vancouver BST Annual Report for 1951/1952, 11.

67 VCA, Report of Dr. C.H. Gundry, Mental Hygiene Division, for 1952, 1.

68 VCA, "Special Services for Elementary and Secondary Schools," Vancouver BST Annual Report for 1953, 11.

69 VCA, Report of Dr. C.H. Gundry, Mental Hygiene Division, for 1953, 1. 
Itzkow had a monthly meeting with school staff "to discuss questions in mental health related to disturbed children in the classroom."70 There is no mention of the children's ethnic or social backgrounds.

Itzkow published a synopsis of his work entitled Reports on the Project Undertaken in Three Vancouver Elementary Schools: Dawson, Lord Roberts, Seymour, September 1953 to June 1955. Lord Roberts was in the west end of the city's downtown, an area of aging Edwardian mansions, many of which had been converted into apartments. Dawson was adjacent to the railway yards of the False Creek industrial area. Seymour was in the heart of east Vancouver near the shipping docks. The project centred around developing a team approach to flagging problem pupils in each school so they could be dealt with by the social worker. Itzkow's assessment of the children is illuminating:

There was no attempt to classify these children as being moderately or severely maladjusted. It could be stated that the behaviour of these children was so different from that of other children that they were considered to be maladjusted and in poor mental health. ${ }^{71}$

The teachers, school nurse, principal, psychologist, psychiatrist, and social worker made up the team. The teachers were the most important members since they would have the most "dealings with the child.” The parents were merely interviewed for information. ${ }^{72}$ Decision-making authority was firmly held by school and medical professionals.

In 1956 Itzkow suddenly resigned from his position to take up an appointment as mental health consultant for the schools of Snyder, Texas. ${ }^{73}$ There is also no further mention of the work of Russell Mackenzie at Templeton. Despite the departure of these two individuals, such issues as student academic failure, delinquency, and behaviour problems were being increasingly regarded as mental health concerns. In 1953 a committee of the Vancouver School Board was organized under Trustee Mrs. H.F.

70 VCA, “Mr. H. Itzkow,” Report of Dr. C.H. Gundry, Mental Hygiene Division, for 1954, 6-7.

71 VCA, Harry Itzkow, Reports on the Project Undertaken in Three Vancouver Elementary Schools: Dawson, Lord Roberts, Seymour, September 1953 to June 1955, 12. 72 Ibid., 15.

73 VCA, Report of Dr. C.H. Gundry, Mental Hygiene Division, for 1956, 1. 
Angus to study the present state and future need for mental health services in the school system. It submitted its report in June, 1954 to the school board. Noting that Dr. C.H. Gundry was to be commended "for his help and courtesy," the study claimed that " $10 \%$ of the school population...showed signs of incipient or overt mental disturbance" and would "benefit by psychiatric diagnosis and treatment." The only specific school mentioned in the report was John Oliver High School, where "only 5\% of the school population or one in every ten of those needing this service, were seen by the Mental Hygiene Clinic."74

John Oliver is located in the southeast part of Vancouver, then an area of working-class and immigrant families. The committee recommended that a resident mental health co-ordinator be appointed to the school. In June, 1954, Angus appealed to the Canadian Mental Health Association as such a service was beyond the means of the school board. Around the same time an article appeared in one of the city's newspapers with the headline: "10 Percent of City Students Believed Mentally Disturbed.” It stated that a "serious lack of mental facilities" were to be found in the neighbourhood of "the John Oliver High School area, Forty-first and Fraser."75 The Angus report led the school board to believe that mental problems were the root cause of school problems, especially on the city's east side.

The mid-1950s marked the greatest period of interest in mental hygiene and its application to school work. A memo of April, 1954, from Superintendent H.N. MacCorkindale to all principals concerned a mental health talk series that was to be offered in five city high schools on the evening of Wednesday, May 5th. The outline for the series covered: "Mental Health in the Family" at Templeton Junior High (east side); "Delinquency and Mental Health" at Point Grey Junior High (west side); "Mental Health Services in the School System” at Gladstone Junior/Senior High (east side); "Teamwork Between Home and School in Promoting Mental Health" at King Edward High (east/west boundary); and "Common Emotional Problems in Everyday Family Living” at Kitsilano Junior/Senior High (west side). It is notable that Gundry

74 VCA, Trustees Mrs. H.F. Angus, Mr. D.M. Owen, and Mr. G.H. Rogers, Report of Special Committee No. 5; Re: Mental Health Services in the Vancouver School System, June, 1954, 1, 4, 8.

75 VCA, Letter of Trustee Mrs. H.F. Angus to Mrs. William Irwin, Canadian Mental Health Association, 16 June 1954; "Committee Estimate: 10 Percent of City Students Believed Mentally Disturbed,” Vancouver Sun, 8 June 1954, 1. 
himself did not speak in the talk series. It is also quite significant that the talk on delinquent youth was given to affluent west-side parents while east-side parents were provided with information on family services offered by the school system. ${ }^{76}$

In 1955 a major initiative was launched utilizing a "mental hygiene grant" from the Federal Department of Health. It provided for "inservice training in mental hygiene for counsellors" in many Vancouver schools. The purpose of the initiative was to make not only counsellors but also "principals...sensitive to the mental hygiene needs of children.” In 1955 there were 137 new and 38 repeat cases; a comparison of east-side to west-side high schools reveals a startling contrast. On the east side Templeton Jr. High, John Oliver, and Gladstone accounted for 22 referrals for mental hygiene consultations. On the west side Kitsilano Jr. High, Point Grey Jr. High, and Prince of Wales High School provided only 5 cases. There were 81 cases of poor school progress, 55 conduct disorders, and 14 pupils with adolescent character disorders. The sex ratio of cases dominated by males (106) with few females (69) continued. $^{77}$

During 1956 the first special counsellors were ready to begin their work. Eight were initially assigned to district secondary schools and visited each high school's feeder elementary schools. They spent half-days at neighbourhood elementary schools and were based in a local secondary school. The success of the program was so encouraging that Gundry stated "we hope that it can be carried on indefinitely." Due to higher school enrolment in 1956 and the "increasing awareness of the value of mental health," Gundry experienced a higher demand for diagnostic and treatment services. As in all previous years, the cases in secondary schools treated in 1956 seemed to be centred on the east side of Vancouver. Templeton Jr. High, Britannia, John Oliver, Gladstone, and the Technical High School referred 31 cases from the east side. Point Grey Jr. High, Prince of Wales, Kitsilano and King Edward High Schools from the west side sent Gundry 9 cases. The special counsellors on the east side were extremely busy. An east-side school like Templeton Jr. High and its feeder schools, Begbie, Lord Nelson, and Hastings, provided 12 cases alone. Compare this to Point Grey Jr. High on the west side and its feeder schools,

76 VCA, H.N. MacCorkindale, Superintendent, "Special Invitation to Principals and Teachers, 28 April 1954.”

77 VCA, Report of Dr. C.H. Gundry, Mental Hygiene Division, for 1955, 1-6. 
Quilchena and Kerrisdale, which only yielded 6 cases. The majority of cases continued to be boys (124) with only a limited number of girls (48) ${ }^{78}$

During the 1957/1958 school year 13 special counsellors "had more than 3,000 consultations with teachers.” Gundry reported that "one of the original special counsellors has become a principal.” Dr. Norman Ellis, a psychologist in the Vancouver school system from 1957 to 1978, recalls that the special counsellors' program was a well-known career advancement vehicle. There were 141 new and 53 repeat cases in 1957 of which 131 were boys and 63 girls. A staggering 109 pupils were referred for "poor school progress" while 38 exhibited "conduct disorders." East-side high schools provided the bulk of referrals; Britannia, John Oliver, Templeton, Gladstone, and the Vancouver Technical had 25 cases combined, while Lord Byng, Prince of Wales, Kitsilano, and Point Grey provided only 9 cases from the west side. East-end elementary schools like Begbie (5), Strathcona (7) and Nelson (6) referred more pupils than their west-side counterparts, Henry Hudson (2), General Gordon (2), Bayview (1), and Queen Mary (2). ${ }^{79}$ The 1958/1959 report of the School Health Services made it clear the special counsellors' assessments and examinations were not being included in the 264 "active cases" of the Mental Hygiene Division. Gundry's staff had "carried out almost a thousand treatment interviews." 80

Gundry's report for 1958 shows that 155 referrals were made for "poor school progress" while the high school case data reveals the same disproportionate east/west split. On the east side Britannia, Gladstone, John Oliver, Templeton, and Vancouver Technical sent Gundry 27 cases. On the west side Lord Byng, King Edward, Kitsilano, Magee, Point Grey, and Prince of Wales only provided 13 cases. Boys remained ever-dominant with 178 cases compared to 59 for girls. ${ }^{81}$ An example of how privileges were being extended to high-achieving students drawn largely from west-side schools was the gifted pupil program where "all superior children...would follow an enriched curriculum.” The board made

78 VCA, Report of Dr. C.H. Gundry, Mental Hygiene Division, for 1956, 1-7; “Mental Hygiene Services," Vancouver BST Annual Report for 1956/1957, 18.

79 VCA, “Consultative Services,” Vancouver BST Annual Report for 1957/1958, 4; Interview with Dr. Norman Ellis, 25 Jan. 1997; VCA, Report of Dr. C.H. Gundry, Mental Hygiene Division, for 1957, 1-8.

80 VCA, Dr. Stewart Murray, “School Health Services,” Vancouver BST Annual Report for 1958/1959, 18.

81 VCA, Report of Dr. C.H. Gundry, Mental Hygiene Division, for 1958, 1-9. 
$\$ 10,000$ available to purchase materials as a part of this gifted education. Dr. Ellis directed a secondary program to have talented math and science students meet with "scientists from the business world and industrial world" every week for two hours of mentoring. According to Ellis, many of the grade 11 and 12 students in the program went on to university scholarships. ${ }^{82}$ It is clear that the gifted program for west-side, middle-class students formed a counterpart to the mental hygiene counselling initiatives for east-side delinquents. The gifted program expanded social possibilities for middle-class students while the Mental Hygiene Division sought to control the anti-social tendencies of east-side children from ethnic/working-class backgrounds.

In 1956 the special counsellors' program was expanded and began training personnel from neighbouring suburban municipalities such as Surrey and Coquitlam. From 1956 to 1960 a total of 31 counsellors were trained. ${ }^{83}$ In his 1959 report, Gundry noted with pride that the special counsellors were "having a favourable effect on the thoughtfulness with which the problems of individual children are being considered throughout our schools." However, in 1959 the data for case numbers per school in Vancouver ceased to be entered. Gundry did a special study on "85 adolescent boys" who "were displaying serious academic failure." After administering intelligence testing he found no evidence of low intellect; it had to be their families that were at fault. To Gundry the only "successful treatment of these boys...demands that they be under control for a lengthy period of time... away from their own homes, in a situation where their programme is guided for 24 hours a day by psychiatric principles." ${ }^{4}$ During the years 19491958, for which Gundry presented sex ratio case data, boys were by far the largest clientele of his services. It is surprising to find this project was his only case study of delinquent boys. Gundry makes no references to the ethnic or social backgrounds of these boys and leaves it to his readers to surmise the fact they came from the city's east side. By the end of the 1950s Gundry proposed the same solution to the problem of wayward male youngsters as during the early part of the twentieth century with eugenics, their removal to

82 Interview with Dr. Norman Ellis, “Gifted Pupil Programme”; VCA, Vancouver BST Annual Report for 1958/1959, 5.

83 VCA, "Special Counsellors' Programme," Vancouver BST Annual Report for 1959/1960, 8.

84 VCA, Report of Dr. C.H. Gundry, Mental Hygiene Division, for 1959, 1-7. 
a segregated institutional setting. ${ }^{85}$ Even Gundry had come to recognize reluctantly that mental hygiene had its therapeutic limitations.

\section{Conclusion: The Decline of Mental Hygiene in the 1960s}

In 1961 the first significant decline occurred in the activities of the Mental Hygiene Division as more of its functions were moved to the school level. Over 111 children were used as "teaching cases" for school nurses and 14 special counsellors treated over 300 children through interviews. Gundry noted in his report that there would have to be "an acceptance of limitations, and economy of treatment" in the cases he dealt with. ${ }^{86}$ In 1962 Gundry had an unusually large number of boys referred to the clinic between ages six and twelve. It was consistent with the preponderance of males he had dealt with since the mid-1940s. All were found to be of "normal ability" but were nevertheless "showing learning problems." ${ }^{87}$ This population of schoolchildren was by 1963 beginning to be defined as "learning disabled" after the definition by Samuel Kirk, who held that children of average to above-average intelligence who showed signs of significant learning problems constituted a separate category from those previously defined as low-achieving pupils. They had a "processing dysfunction" that could be remediated through new instructional techniques. ${ }^{88}$

Gundry seemed unaware of these new developments in learning disabilities and instead diagnosed the boys he interviewed as being anxiety-ridden. ${ }^{89}$ Recalling his army days, he argued that the solution was not to be over-protective or to "coddle" the children but have them face their problems by trying "to teach them

85 A.J. Dauphinee, “An Appeal for the Feeble Minded,” Western Woman's Weekly 1, 5 (10 Jan. 1918): 2.

86 VCA, “Mental Health Services,” Vancouver BST Annual Report for 1960/1961, 21; VCA, Report of Dr. C.H. Gundry, Mental Hygiene Division, for 1960/1962, 2.

87 VCA, "Mental Hygiene Services," Vancouver BST Annual Report for 1961/1962, 18. 88 Joseph K. Torgesen, "Learning Disabilities: Historical and Conceptual Issues," in Learning About Learning Disabilities, ed. Bernice Y.L. Wong (Toronto: Academic Press, 1991), 14; Janet W. Lerner, Learning Disabilities: Theories, Diagnosis, and Teaching Strategies (Boston: Houghton Mifflin Press, 1981); Lerner states: "[there are] children in every classroom who can be identified as learning disabled, and they are four to six times more likely to be boys than girls," 17.

89 VCA, Report of Dr. C.H. Gundry, Mental Hygiene Division, for 1961/1962, 2. 
to want to do what they should do."90 By 1964 there were 57 teachers and 902 pupils in classes for slow learners at the elementary as well as secondary levels in Vancouver's schools. Gundry had to admit "that many children with learning difficulties can be helped by an individualized programme." ${ }^{1}$ In 1965 plans were under way for city-wide remedial reading classes and many schools were dealing with their problem children through schoolbased counselling services. The growth of counselling services "has decreased the need for referrals to mental hygiene clinics" and Gundry was moving towards "more consultation service to schools.” By 1966 the schools were being "encouraged to integrate slow learners into regular class academic work and into the social life of the school in general." The remedial reading classes enrolled 3,342 pupils. Gundry complained he was seeing "rather fewer children." 92 More direct counselling services and remedial teaching at the school level had decreased the number of children being referred to the mental hygiene clinic. If such educational provisions had been adopted in previous decades a rapid decline in the perceived mental problems of schoolchildren would likely have occurred.

In 1967 Gundry was forced to recognize that "children with learning difficulties" would constitute the focus of the clinic's activities. However, his attitude about what would ameliorate these learning difficulties remained unchanged: simple school consultations could “"nip in the bud'many emerging problems of youngsters and will completely prevent others."93 Grappling with the effects of poverty on student under-achievement, long-term remediation for learning disabilities and ongoing counselling assistance to guide a student's school program entailed the development of totally new school resources. Small chats with a mental hygienist were simply not going to address the problems of such students. In 1968 the Vancouver School Board recognized that the needs of students were evolving and their services to them had to expand accordingly. Learning-assistance teachers, diagnostic testing services, special classes for non-English-

90 VCA, Metropolitan Health Committee Minutes, Wednesday, 19 Sept. 1962, Item \#2. 91 VCA, Report of Dr. C.H. Gundry, Mental Hygiene Division for 1963/1964, 2. 92 VCA, "Special Counsellors," "Slow Learners," "Reading Problems,” Vancouver BST Annual Report for 1965/1966, 21, 24, 9; VCA, Report of Dr. C.H. Gundry, Mental Hygiene Division, for 1965/1966, 1.

93 VCA, “Mental Hygiene,” Vancouver BST Annual Report for 1966/1967, 32; VCA, Report of Dr. C.H. Gundry, Mental Hygiene Division, for 1966/1967, 1. 
speaking children, and summer Head Start programs for children expected to exhibit low achievement in Grade One constituted a "gradually changing pattern of education in Vancouver." Gundry remained adamant that the "principles of mental hygiene can be applied to the study of the predicament of large numbers of children.” Fearing his work would be taken over by lesser professionals, Gundry warned that "clinical experience is a necessary background for those who are taking responsibility for consultation." ${ }^{94}$ He was clearly frustrated by the treatment children were receiving at the school level by those who lacked a medical background in mental hygiene. However, Gundry's misgivings soon became a moot point as he retired in September, 1968, due to ill health and died only a year later on July 26, 1969.

In his obituary Dr. Gundry was called a "mental hygiene pioneer" who gave school personnel "the diagnostic tools for spotting mental health problems in children.” At the time of his death Gundry was a consulting psychiatrist at Shaughnessy Hospital and a medical faculty member at the University of British Columbia. ${ }^{95}$ There is little doubt he had a distinguished medical and public service career. However, it is not so much his medical career as his belief in the principles of mental hygiene that are of interest to historians of education. To return to a point made by Angus McLaren: despite mental hygiene's environmental explanation for a child's intellectual/emotional problems being opposed to the eugenicist's hereditarian rationale for inherited social inferiority, both philosophies shared an important common characteristic in that "although their methods differed, their goals of efficient social management were similar." 96 This social management by educated, Anglo middle-class experts of immigrant and working-class families who lacked social power constituted the vital link between eugenics and mental hygiene. The educated classes of society represented by doctors and school personnel attempted to manage socially the diverse, non-conformist pupil populations they came into contact with. In the case of eugenics this management was very overt: institutionalization, segregated educational settings, and sterilization to curb procreation. Mental

94 VCA, “The Gradually Changing Pattern,” “A New Look at Assessment,” "A Head Start Program," "Special Education,” Vancouver BST Annual Report for 1967/1968, 1-23; VCA, Report of Dr. C.H. Gundry, Mental Hygiene Division, for 1967/1968, 2, 4. 95 “Dr. Gundry Funeral Set Today,” Daily Province, 30 July 1969, 10; “Mental Hygiene Pioneer Dies," Vancouver Sun, 29 July 1969, 10. 96 McLaren, Our Own Master Race, 112. 
hygiene was much less overt in that it stressed that such populations displayed mental deviancy which required psychiatric treatment, or the removal of children from the source of this deviancy, often their own families. Eugenics and mental hygiene were both driven by the fears of the Anglo middle-class that they would be overwhelmed by the working class and immigrants.

The eugenicists' preoccupation with controlling the criminal classes, immigrants, and the working class was shared by mental hygienists. Mental hygienists normalized the ideal of Anglo middle-class family life. They turned working-class and nonAnglo minority youths into subjects for the investigation of social deviancy. Gleason states that the "normal family" emerged within a medical discourse which "reproduced the values of the white, middle-class, patriarchal, and heterosexual postwar social order." The socially normal became the "socially sanctioned," which acted like a "levelling force" to minimize social, racial, economic, and cultural differences between individuals in Canadian society. Gleason argues that this normalizing of an ideal childhood and standards for family mental health was a reaction against the social transformations overtaking Canadian society after World War Two. ${ }^{97}$

Gundry's practice of focusing mental hygiene resources in schools with working-class and ethnic minority students in the city's east-side neighbourhoods reveals this Anglo middle-classbased drive to confront the threat of social deviancy as well as delinquency. The east-side and southeast schools of Vancouver were targeted with specific mental hygiene initiatives using special counsellors and social workers. The affluent Anglo middle-class west side remained an area of marginal activity for the Mental Hygiene Division. Normalcy among children and their families was defined on a geographic, class, and ethnic basis by Vancouver's mental hygienists. Few west-side parents were forced into family counselling, but for the working-class and ethnic minority parents of the city's east side, medical authorities had to be obeyed. Historians must appreciate Gundry's role as a powerful social agent who imposed his Anglo middle-class professionalism upon the children and families of working-class people who had a very limited ability to adapt to the dominant social standards. However, the fact that such scenarios are still occurring in so-called "inner city schools" where counselling staff continue to label

97 Gleason, Normalizing the Ideal, 81. 
deprived families as "dysfunctional” and their children as "at-risk" should alert the educational historian to the continuity between the mental hygiene of the past and well-intentioned school-based interventions of today. ${ }^{98}$

98 Barry M. Franklin, From Backwardness to At-Risk: Childhood Learning Difficulties and the Contradictions of School Reform (Albany: State University of New York, 1994), 71-72, 141-42. For the east/west divide in Vancouver school reading performance see “Reading Wars: Competing Styles," Vancouver Sun, 23 Nov. 2001, B6 for a map clearly showing test data from the city's east-side schools for grades 4, 7 and 10 as having "reading scores below the district average." 